\title{
Significance of Rhamnolipids as a Biological Control Agent in the Management of Crops/Plant Pathogens
}

\author{
Oluwaseun $\mathrm{AC}^{1,2 *}$, Phazang $\mathrm{P}^{2}$ and Sarin $\mathrm{NB}^{2}$ \\ ${ }^{1}$ Department of Biological sciences, Applied microbiology, Biotechnology and Nanotechnology Laboratory, Landmark University, Nigeria \\ ${ }^{2} J a w a h a r l a l ~ N e h r u$ University, India
}

Submission: November 01, 2017; Published: December 11, 2017

*Corresponding author: Oluwaseun AC, Department of Biological sciences, Applied microbiology, Biotechnology and Nanotechnology laboratory, Landmark University, Nigeria, Email: adetunjicharles@gmail.com

Abstract

Rhamnolipids has been recognised as a safe biosurfactant with diverse and unique properties and could be a permanent replacement to the synthetic chemicals used in the management of plant pathogens. With regard to this, the review intends to report the recent applications of rhamnolipids in the management of plants pathogens.

\section{What are Rhamnolipids}

Rhamnolipids are bio surfactants, which are glycolipidic in nature containing carbohydrates and hydroxyl aliphatic acids. They are produced by $P$. aeruginosa strains and are one of the most studied glycolipid biosurfacants. They have a hydrophobic tail that contains one or two fatty acids joined to the carboxyl end of one or two rhaminose molecules referrred to as monorhamnolipid and dirhamnolipid respectively [1].

\section{Reported Attributes of Rhamnolipids}

Various scientists have described the significance of rhamnolipids in industries, pharmacy and agriculture. Their special attributes that make them unique include low toxicity, selectivity, rapid biodegradation, easy mass production on cheap substrates, stability under different environmental conditions and environment friendly. These diverse properties are making rhamnolipids the ecological alternative for the synthetic biosurfactants [2-5].

\section{Modes of Action of Rhamnolipids}

The biological control activities of rhamnolipids produced by Pseudomonas aeruginosa strains could be linked to their ability to liberate the intracellular contents of targeted pathogens by causing disruption and lyses of the cells [6,7]. They act on the target cells by disrupting the lipid content and proteins of cell membranes thereby changing the configuration of the cell wall and osmolarity of the cell. This subsequently leads to increase in their toxicity on pathogenic microorganisms [8].
Recent Advances in the Utilization of Rhamnolipids for the Management of Bacterial and Fungal Crop Pathogens

Rhamnolipid biosurfactants isolated from various $P$. aeruginosa strains have potential applications in agriculture because of their antimicrobial properties in addition to being a biosurfactant and their ability to induce non specific-immunity in plants [9]. In-vitro studies reported the efficacy of rhamnolipids against gram-negative bacteria like Ralstonia solanacearum responsible for causing bacterial wilt in tobacco, tomato, pepper and potato plants and Xanthomonas campestris responsible for black rot in cruciferous vegetables [10]. Antifungal properties of rhamnolipids have also been established in vitro against zoosporic phytopathogens like Botrytis sp., Rhizoctonia sp. Pythium sp., Phytophtora sp. [11,12] Mucor miehei and Neurospora crassa [13]. The zoospores do not possess cell walls. They are surrounded only by plasma membrane. Rhamnolipids target them by interacting with the plasma membrane resulting in disintegration of the membrane and finally lyses of the cells [11]. In vitro growth inhibition assay also showed that rhamnolipids affected the mycelial growth of fungi [10].

Studies of antifungal properties of rhamnolipids have also been extended in vivo in plant systems, particularly crop plants. Application of rhamnolipids protected the pepper plants from Pytopthora blight disease. Similarly, treatment of cucumber plants with rhamnolipids prevented the development of Colletotrichum orbiculare on the leaves [10]. Studies further 
conducted by Yoo et al. [14] showed the potential application of rhamnolipids in preventing water borne damping off disease in plants caused by phytopathogenic oomycetes Phytophthora sp. and Pythium sp. Sharma et al. [15] further corroborated the results in chilli pepper and tomato plants. In another study conducted by Millioli et al. [16] application of rhamnolipids together with $R$. glutinis showed bioactivity against A. alternate, a serious pathogen causing post harvest black rot in certain cultivars of plants.

\section{Conclusion and Recommendation}

Though chemical pesticides and fungicides have helped in controlling the outbreaks of plant diseases, their longterm use is not feasible because of their adverse effects on environment. Thus, the search for eco-friendly alternatives has driven interdisciplinary research leading to the discovery of many potential molecules of biological origin. Rhamnolipids is one of them $[16,17]$. Because of their diverse properties as stated earlier, they are in the pipeline for large-scale use in controlling crop pathogens. This review has highlighted the use of rhamnolipids in the biological control of plant bacterial and fungal pathogens. The further application of functional meta genomics will assist in the discovery of more strains with high yield, stability, and better attributes. Also, more focus is required on identifying the non-target effects of rhamnolipids in their use as biological control agents against plant pathogens.

\section{References}

1. Adetunji C, Oloke JO, Pradeep M, Jolly RS, Anil KS, et al. (2017a) Characterization and optimization of a rhamnolipid from Pseudomonas aeruginosa C1501 with novel biosurfactant activities. Sustainable Chemistry and Pharmacy 6:26-36.

2. Maqsood IM, Shams SM (2014) Rhamnolipids: well-characterized glycolipids with potential broad applicability as biosurfactants. Ind Biotechnol 10(4): 285-291.

3. Sajna KV, Höfer R, Sukumara RK, Gottumukkala LD, Pandey A (2015) White biotechnology in biosurfactants. In: Pandey A, Höfer $\mathrm{R}$, Taherzadeh M, Nampoothiri M, Larroche C (Eds.), Industrial Biorefineries \& White Biotechnology, Elsevier, Netherland, pp. 499521.

4. Eraqi WA, Yassin AS, Ali AE, Amin MA (2016) Utilization of crude glycerol as a substrate for the production of rhamnolipid by Pseudomonas aeruginosa. Biotechnology Research International 2016:
$1-10$.

5. Adetunji C, Oloke J, Kumar A, Swaranjit S, Akpor B (2017b) Synergetic effect of rhamnolipid from Pseudomonas aeruginosa C1501 and phytotoxic metabolite from Lasiodiplodia pseudotheobromae C1136 on Amaranthus hybridus L. and Echinochloa crus-galli weeds. Environ Sci Pollut Res 24(15): 13700-13709.

6. Banat IM, Franzetti A, Gandolfi I, Bestetti G, Martinotti MG, et al. (2010) Microbial biosurfactants production, applications and future potential. Appl Microbiol Biotechnol 87(2): 427-444.

7. Cameotra SS, Makkar RS (2004) Recent applications of biosurfactants as biological and immunological molecules. Curr Opin Microbiol 7(3): 262-266.

8. Mawgoud AM, Lépine F, Déziel E (2010) Rhamnolipids: Diversity of structures, microbial origins and roles. Appl Microbiol Biotechnol 86(5): 1323-1336.

9. Sachdev DP, Cameotra SS (2013) Biosurfactants in agriculture. Appl Microbiol Biotechnol 97(3): 1005-1016.

10. Kim BS, Lee JY, Hwang BK (2000) In vivo control and in vitro antifungal activity of rhamnolipid B, a glycolipid antibiotic, against Phytophthora capsici and Colletotrichum orbiculare. Pest Management Science 56(12): 1029-1035.

11. Stanghellini ME, Miller RM (1997) Biosurfactants: Their identity and potential efficacy in the biological control of zoosporic plant pathogen. Plant disease 81(1): 4-12.

12. Varnier AL, Sanchez L, Vatsa P, Boudesocque L, Brugger GA, et al. (2009) Bacterial rhamnolipids are novel MAMPs conferring resistance to Botrytis cinerea in grapevine. Plant Cell Environ 32(2): 178-193.

13. Nitschke M, Costa SG, Contiero J (2010) Structure and applications of a rhamnolipid surfactant produced in soybean oil waste. Appl Biochem Biotechnol 160(7): 2066-2074.

14. Yoo DS, Lee BS, Kim EK (2005) Characteristics of microbial biosurfactant as an antifungal agent against plant pathogenic fungus. Journal of Microbiology and Biotechnology 15(6): 1164-1169.

15. Sharma A, Jansen R, Nimtz M, Johri BN, Wray (2007) Rhamnolipids from the rhizosphere bacterium Pseudomonas sp. GRP(3) that reduces damping-off disease in Chilli and tomato nurseries. Journal of Natural Products 70(6): 941-947.

16. Millioli V, Servulo EL, Sobral L, Carvalho D (2009) Bioremediation of crude oil- bearing soil: Evaluating the effect of rhamnolipid addition to soil toxicity and to crude oil biodegradation efficiency. Global Nest 11(2): 181-188.

17. An CJ, Huang GH, Wei J, Yu H (2011) Effect of short-chain organic acids on the enhanced desorption of phenanthrene by rhamnolipid biosurfactant in soil water environment. Water Res 45(17): 55015510 .

\begin{tabular}{|l|}
\hline Your next submission with Juniper Publishers \\
will reach you the below assets \\
- Quality Editorial service \\
- Swift Peer Review \\
- Reprints availability \\
- E-prints Service \\
- Manuscript Podcast for convenient understanding \\
- Global attainment for your research \\
- Manuscript accessibility in different formats \\
( Pdf, E-pub, Full Text, Audio) \\
- Unceasing customer service \\
Track the below URL for one-step submission \\
https://juniperpublishers.com/online-submission.php \\
\hline
\end{tabular}

